\title{
Systematics, phylogeny and biogeography of the Meliponinae (Hymenoptera, Apidae): a mini-review
}

\author{
JMF de Camargo, SR de Menezes Pedro \\ Departamento de Biologia da Faculdade de Filosofia, Ciências e Letras de Ribeirão Preto, \\ Universidade de São Paulo, 14040-901, Ribeirão Preto, SP, Brazil
}

(Received 15 November 1991; accepted 10 July 1992)

\begin{abstract}
Summary - The main proposals for systematics, phylogeny and biogeography of the Meliponinae, and the polarity and significance of some morphological characters are discussed. Although a set of probable synapomorphies is suggestive of the Meliponinae as a co-phyletic group with the Apinae, Bombinae and Euglossinae, the relationships with these subfamilies remain unclear. The distributional pattern and fossil record are indicative of greater antiquity for the Meliponinae and suggestive of an independent origin or an early divergence from a proto-other Apidae branch. The sister-group relationship between Malayan and neotropical Meliponinae (Tetragona-Tetragonisca line and possibly Trigonisca-Pariotrigona, Lisotrigona), and the probable relationship between Austroplebeia and the neotropical Plebeia line, are suggestive of a West-Gondwanan origin for the Meliponinae, with 2 main dispersal routes via the holarctic and panaustral regions.
\end{abstract}

systematics / biogeography / Apidae / Meliponinae / phylogeny

\section{ON THE RELATIONSHIPS OF THE MELIPONINAE AND OTHER APIDAE}

Sakagami and Michener (1987) and Michener (1990) presented strong arguments in favor of the hypothesis that the Meliponinae (M), Apinae (A), Bombinae (B) and Euglossinae (E) constitute a holophyletic clade, the probable sister-group of the Xylocopinae. They included certain characters - absence of basitibial and pygidial plates and nests usually constructed in large or irregular cavities, cells built up rather than excavated in the substrate as possible synapomorphies, in addition to the well known corbicula and rastellum (present in females, except in parasitic and cleptobiotic forms and in queens of the highly eusocial groups). Michener (1990) also included other possible synapomorphies (hind basitarsus of female articulated near anterior end of apex of tibia, reduced maxillary palpus, 1 - or 2- segmented), and other characters, such as form and type of cephalic and thoracic salivary glands and hypopharyngeal glands 
(see also Cruz-Landim, 1967), and commented that this association of character states is an indication "that the 4 subfamilies of Apidae are related to one another, $i e$, that no one of them is an anthophorid group that has convergently evolved the external features of Apidae". Despite these deductions, Michener (1990) did not exclude the possibility that the main characteristic of the Apidae, the complex pollenmanipulating behavior and associated structures, could have arisen independently in 2 or more of the groups included in the Apidae, considering the distinctive mechanical and morphological solutions they present (rastellum and auricula in A and B, rastellum or posterior parapenicillum and penicillum in $M$, and an auricula-like structure in E; of Michener et al, 1978; Wille, 1979a). Even the corbicula (a bare or sparsely haired area on the outer surface on the hind tibia, used for the transport of both sticky material for nest construction and pollen), the principal synapomorphy, and one that, in the opinion of Michener et al (1978), precedes the origin of the highly derived pollen-manipulating behavior and associated structures, is not an exclusive attribute of the Apidae. A corbicular structure also occurs in Canephorula apiformis, an Anthophorinae from Argentina (cf Friese, 1920; Michener et al, 1955). Some of the other possible synapomorphies suggested by Sakagami and Michener (1987) and Michener (1990), ie absence of basitibial and pygidial plates and reduced maxillary palpus indicate loss and may occur independently as in some other Apoidea. Although the set of characters considered here is more indicative of holophyly for the Apidae, the situation becomes more complex when one searches for the synapomorphies indicative of relationships among the 4 taxa, as verified by the different proposals of phylogeny. Winston and Michener (1977) and Kimsey (1984) suggested M as the sister-group of the other Apidae;
Winston (1979), in a study of the mouthparts, suggested a relationship between $M$ and the Xylocopinae, or an early divergence of $\mathrm{M}$ from the other Apidae. Plant and Paulus (1987) considered $E$ as the oldest branch, a sister-group of the other Apidae. Michener (1990) presented 5 of the 15 possibilities of relationship among the 4 taxa; he considered the cladograms where $M-A$ appears as a sister-group of $B-E$, and $E$ as a sister-group of $\mathrm{B}, \mathrm{A}-\mathrm{M}$ more probable: however, from the biogeograhic point of view and possible greater antiquity of $M$, he also considered reasonable the cladograms where this taxa appears as a sister-group of $E, B$ and A. Prentice (1991) suggested $E$ and $B$ as older branches and $A-M$ as sistergroups (as originally proposed by Michener, 1944).

In recent papers, based on mitochondrial and ribosomal DNA sequences, Cameron (1991) and Sheppard and McPheron (1991) proposed the Meliponinae and Bombinae as sister-groups. Although this refined methodological approach may constitute a valuable tool for taxonomy and systematics, the number of Apidae and non-Apidae bees presently analysed is too small to allow inference of phylogenetic relationships.

As previously pointed out by Camargo (1989), none of the propositions on phylogenetic relationships of the Meliponinae with the other Apidae considered congruity with the biogeographic patterns, apart from some considerations presented by Michener (1990:82). $M$ is widely distributed, ranging through the pantropical and southern subtropical regions (cf Moure, 1961); the neotropical region, Africa, south of the Sahara, Madagascar, the Malayan region, $s$ lat including the islands on the east of the Wallace's line (New Guinea, Sakagami et al, 1990), the eastern Indian subcontinent, New Guinea, and northeastern Australia, with several hundred species and many supra-specific taxa (21 recent genera, according to Michener 1990; and 54 accord- 
ing to Camargo 1989, besides 3 extinct genera). This distribution pattern and the antiquity (the oldest known bee fossil, Trigona prisca from late Cretaceous New Jersey - USA amber, 96-74 mya, is very similar to the recent species of Trigona $s$ str from the neotropics; of Michener and Grimaldi, 1988a,b; Grimaldi et al, 1989) suggest that $M$ is an ancient group, possibly Gondwanan (see item Origin, phylogeny and biogeography), 100-130 mya old (Michener, 1979; Camargo and Wittmann, 1989 respectively). The other taxa seem to be more recent (Michener, 1990), except possibly $B$. $E$ is limited to the neotropics (basically in tropical areas), and is presumably post-Gondwanan. A is a typical IndoMalayan group. Amongst the 9 recent species admitted ( $c f$ Michener, 1990; see also comments by Alexander, 1991), only 1 occurs in Eurasia and Africa and another in Indo-Malaya and east Asia, the other species, including the most conservative forms (the dorsata and florea complex; Camargo, 1972; Ruttner, 1988; Alexander, 1991) are found in the indo-Malayan region up to Timor. Representatives of A are absent in New Guinea and Australia (cf Ruttner, 1988; Michener, 1990). Fossil records from Oligocene-Miocene Europe indicate forms that are apparently related to the $A$ mellifera group according to Zeuner and Manning (1976); on the basis of forewing morphometric analysis of Synapis and Apis armbrusteri, Ruttner (1988) suggested approximation with the Apis dorsata group. Such taxonomic and distributional patterns might indicate that $A$ is less ancient than $M$ (cf Michener, 1990), and evolved well after the breakup of Gondwana (cf Roubik, 1989), possibly after formation of the Himalayas (it could be hypothesized that Apis evolved in isolation in the Indian subcontinent while it was still an island!). Thus, a direct derivation of $M$ from the $A$ or $E$ branch is quite unlikely. $B$ is holarctic (ca 250 morphologically homogeneous spp; $c f$
Michener, 1990), with a few species reaching South America (probably a not very ancient migration; of Simpson and Neff, 1985) and mountain areas in the south of the Himalayas. In Africa, it ranges up to the Northern Sahara - fossil forms attributed to the genus Bombus have been recorded from the Oligocene-Miocene in palearctic and nearctic regions (Zeuner and Manning, 1976). A relationship with a proto-Bombinae branch is possible if the origin of the Meliponinae in the Laurasian continent is considered, as suggested by Michener (1990).

It is clear that the Apidae complex still remains an incognita. The geographic vicariance patterns and fossil record, however, support the hypothesis of greater antiquity for $M$ compared with $A, B$ and $E$, and that $M$ presents a considerably remote relationship, or possibly no direct relationship with the other Apidae.

\section{The Meliponinae tribes}

Moure $(1946,1951)$ divided the Meliponinae into the tribes Meliponini Börner 1919 (genus Melipona), Lestrimelittini Moure 1946 (genus Lestrimelitta, maintaining Cleptotrigona apart, since he did not know it de visu) and Trigonini Moure 1946 (the remaining genera). Moure (1961:183; Moure et al, 1958:491) suppressed the Lestrimelittini, incorporating the genus into the Trigonini.

The genus Melipona is exclusively neotropical and, according to Moure (1951), a post-Gondwanan derivative group and so more recent than the main lines of the Meliponinae. Moure $(1951,1961)$ and Wille (1979b) admitted a cleavage line between the Plebeia line and Melipona. In the cladogram presented by Michener (1990; fig 6), Melipona arises isolated at the base as a sister-group of the other Meliponinae; however, this author recognized ( $p$ 92) that this genus is reasonably closely related to Ple- 
beia. Michener (1990:112) suggested the suppression of tribal status for Melipona.

\section{The Meliponinae genera}

The outline of modern systematics of the Meliponinae began with the monumental revision made by Schwarz (mainly 1932, 1948 ) and the comprehensive synthesis by Moure $(1951,1961)$. A critical revision was presented by Wille (1979b), and some comments were made by Camargo (1989). Recently, a detailed and comprehensive paper was published by Michener (1990), taking into account unknown characters or those not much explored by other authors.

Schwarz (1948) recognized 3 genera for the entire world (Melipona, Lestrimelitta and Trigona, including 18 subgenera). He mainly studied the neotropical and Indo-Malayan fauna. For the neotropical region, Moure (1951) proposed 12 genera and 19 subgenera. In 1961, when he reviewed the old world Meliponinae, he recognized 13 genera for the Indo-Malayan and Australian regions, 10 for the Ethiopian region and 11 genera and 24 subgenera for the neotropics. Finally, in a short note, Moure (1971) proposed an identical approach to that of the old world Meliponinae, elevating all subgenera to generic status. This position was reasserted more categorically by Camargo and Moure (1988) and Camargo (1989).

Wille (1979b) centered his criticisms mainly on Moure's view, and pointed out a new systematic arrangement for the subfamily (8 genera and 14 subgenera, making synonymous 30 of the subgenera admitted by Moure).

Camargo and Moure (1983) proposed the genus Trichotrigona for an aberrant form of Meliponinae found in the Amazon. Moure (1989a,b) described Camargoia for pilicornis Ducke and camargoi Moure, 2 divergent forms of the neotropical Tetragona line, and Sakagamilla, a monotypic genus, here considered as synonymous with Scaptotrigona, since it shows all the autapomorphies of the latter without enough relevant discontinuity to be recognized as an independent clade.

Finally, Michener (1990) suggested for the entire world 21 genera and 17 subgenera (one of them new, Papuatrigona Michener et Sakagami, included in Trigona), and made synonymous 19 of the general admitted by Moure (table l).

For the fossil forms, the genera Kelneriapis Sakagami, $1978 \quad(=$ Kelnermelia Moure in Moure and Camargo, 1978), type species Trigona (Hypotrigona) eocenica Kelner-Pillaut, from the later Eocene Baltic amber, Proplebeia Michener 1982 type species, Trigona (Liotrigona) dominicana Wille et Chandler, presumably from the Oligocene amber, Dominican Republic, and Meliponorytes Tosi 1896, type species $\mathrm{Me}$ liponorytes succini Tosi, from the Miocene Sicilian amber, have been described.

Trigona prisca Michener and Grimaldi, the oldest fossil described up to now, 9674 mya, from Cretaceous New Jersey (USA) amber, was considered to be directly related to Trigona (s str) an extant neotropical genus (Michener and Grimaldi, 1988a,b). Such a taxonomic position, however, is dubious (cf Camargo and Wittmann, 1989; Michener, 1990:106). Comments on other fossils of recent genera, and some others which had not been completely studied, were provided by Zeuner and Manning (1976), Wille (1977), Moure and Camargo (1978) and Michener (1990).

\section{ORIGIN, PHYLOGENY AND BIOGEOGRAPHY OF THE MELIPONINAE}

The greatest Meliponinae diversity is found in the neotropics (30 supra-specific taxa 
Table I. Genera and subgenera of Meliponinae admitted by Michener (1990) and after Moure (1961), Camargo and Moure (1988), Camargo (1989) and accepted in the present text. Gen = genus, $(S G)=$ subgenus, syn = synonymous. $\mathrm{N}$ = neotropical region, $\mathrm{E}=$ Ethiopian region, $\mathrm{AU}=$ Australia, NG $=$ New Guinea, MD = Madagascar, $I=$ India, $M A=$ Malayan region .

\begin{tabular}{lc}
$\begin{array}{l}\text { Michener } \\
\text { (1990) }\end{array}$ & $\begin{array}{c}\text { After Moure (1961) } \\
\text { and Camargo (1989) }\end{array}$ \\
\hline
\end{tabular}

\begin{tabular}{|c|c|}
\hline & Tetragonisca-Tetragona Line \\
\hline Gen & Lestrimelitta Friese $1903(\mathrm{~N})$ \\
\hline Gen & Dactylurina Cockerell 1934 (E) \\
\hline Gen () & Trigona Jurine $1807(\mathrm{~N})$ \\
\hline (SG) & $\begin{array}{l}\text { Tetragona Lepeletier } \\
\text { Serville } 1828(\mathrm{~N})\end{array}$ \\
\hline syn & Ptilotrigona Moure 1951 (N) \\
\hline & Camargoia Moure 1989 (N) \\
\hline (SG) & Geotrigona Moure $1943(\mathrm{~N})$ \\
\hline (SG) & Frieseomelitta Ihering $1912(\mathrm{~N})$ \\
\hline (SG) & Duckeola Moure $1944(\mathrm{~N})$ \\
\hline (SG) & Tetragonisca Moure $1946(\mathrm{~N})$ \\
\hline (SG) & Homotrigona Moure 1961 (MA) \\
\hline (SG) & Heterotrigona Schwarz 1939 (MA) \\
\hline syn & Platytrigona Moure 1961 (NG, MÁ) \\
\hline syn & Lophotrigona Moure 1961 (MA) \\
\hline syn & Tetragonula Moure 1961 (I, MA, NG, AU) \\
\hline syn & Tetragonilla Moure, 1941 (MA) \\
\hline syn & Geniotrigona Moure 1961 (MA) \\
\hline syn & Odontotrigona Moure 1961 (MA) \\
\hline syn & Tetrigona Moure 1961 (MA) \\
\hline syn & $\begin{array}{l}\text { Trigonella Sakagami et Moure } \\
\text { (in Sakagami 1975) (MA) }\end{array}$ \\
\hline (SG) & Lepidotrigona Schwarz 1939 (I, MA) \\
\hline (SG) & $\begin{array}{l}\text { Papuatrigona Sakagami } \\
\text { and Michener } 1990 \text { (NG) }\end{array}$ \\
\hline Gen & $\begin{array}{l}\text { Trichotrigona Camargo } \\
\text { and Moure } 1983(\mathrm{~N})\end{array}$ \\
\hline Gen & Oxytrigona Cockerell $1917(\mathrm{~N})$ \\
\hline Gen & Cephalotrigona Schwarz 1940 (N) \\
\hline & Hypotrigona Line \\
\hline Gen & Hypotrigona Cockerell $1934(\mathrm{E})$ \\
\hline Gen & Pariotrigona Moure 1961 (MA) \\
\hline Gen & Lisotrigona Moure 1961 (I, MÁ) \\
\hline Gen & Liotrigona Moure 1961 (E, MD) \\
\hline Gen & Trigonisca Moure $1950(\mathrm{~N})$ \\
\hline syn & Leurotrigona Moure 1950 (N) \\
\hline syn & Celetrigona Moure $1950(\mathrm{~N})$ \\
\hline syn & Dolichotrigona Moure $1950(\mathrm{~N})$ \\
\hline Gen & Cleptotrigona Moure $1961(\mathrm{E})$ \\
\hline
\end{tabular}

Plebeia Line and associates

Gen () Pleibeia Schwarz 1938 (N)

syn Mourella Schwarz 1946 (in Moure, 1946) (N)

syn Friesella Moure $1946(\mathrm{~N})$

(SG) Schwarziana Moure 1943 (N)

(SG) Scaura Schwarz 1938 (N)

syn Schwarzula Moure 1946 (N)

(SG) Nogueirapis Moure 1953 (N)

Gen Austroplebeia Moure 1961 (NG, AU)

Gen Plebeina Moure 1961 (E)

Gen Partamona Schwarz 1939 (N)

syn Parapartamona Schwarz 1948 (N)

Gen Melipona Illiger $1806(\mathrm{~N})$

Gen () Meliponula Cockerell 1934 (E)

(SG) Meliplebeia Moure 1961 (E)

syn Plebeiella Moure 1961 (E)

syn Apotrigona Moure 1961 (E)

(SG) Axestotrigona Moure 1961 (E)

Gen Nannotrigona Cockerell $1922(\mathrm{~N})$

Gen Scaptotrigona Moure 1942 (N) (n syn Sakagamilla Moure 1989)

Gen Paratrigona Schwarz 1938 (N)

syn Aparatrigona Moure $1951(\mathrm{~N})$

and $>300$ described forms) and IndoMalayan regions (14 supra-specific taxa and ca 60 forms). In Africa (10 supraspecific taxa and ca 50 forms), Madagascar (1 supra-specific taxon and 4 forms), Australia (2, 8-10) and New Guinea $(4,5)$, the diversity is much lower.

In this taxon the continental disjunctions are unique within the Apoidea (Michener, 1979), as a result of which a very complex history of vicariance events and great antiquity is presumed. However, there are some obscure points in the taxonomic structure that do not permit a complete reconstruction of the phylogeny of the group. There have been few proposals on the phylogeny (cf Moure, 1951, 1961; Wille, $1979 b)$. Michener (1990) presented a cladistic approach suggesting that the Meliponinae originated in North America (West Laurasia); nevertheless, there is a certain difficulty in accepting the model, in view of some taxonomic problems. 
To analyze the hypothesis on the geograhic origin of the Meliponinae and the possible sequence of events determining the present disjunction pattern, it is necessary to first clarify some questions on the relationships among the taxa: which groups can be recognized as sistergroups?

Moure $(1951,1961)$ proposed at least 3 main phyletic lines, TetragoniscaTetragona, Plebeia and Hypotrigona, present in several continents, based principally on the character form of the micropilose structure (= keirotrichia; Michener, 1990) of the inner surface of the hind tibia of the workers.

\section{The Tetragonisca-Tetragona line}

Michener (1990: 87, character 4), questioned the polarity of this character state. However, he considered elevated and narrow keirotrichia, restricted to the median longitudinal band, leaving a broad bare (or with sparse bristles) depressed posterior margin, as an apomorphic state (Moure, personal communication) consider it primitive or plesiomorphic), and suggested the Malayan Trigona (sensu Michener) as a sister-group of the neotropical Trigona. This character state is present in Trigona (s str), Tetragona, Frieseomelitta, Geotrigona, Duckeola, Tetragonisca, Ptilotrigona, Trichotrigona, Camargoia, Oxytrigona and Cephalotrigona from the neotropical region and in Homotrigona, Heterotrigona, Platytrigona, Lophotrigona, Tetragonula, Tetragonilla, Geniotrigona, Odontotrigona, Tetrigona, Trigonella and Papuatrigona from the Malayan region and the eastern Indian subcontinent (Platytrigona ranges as far as New Guinea; Tetragonula ranges as far as the Solomon Islands, Caroline Islands, New Guinea and northeastern Australia; Papuatrigona is restricted to New Guinea). In Africa, only Dactylurina presents such a state. In the fossil forms, it is present in $T$ prisca (Michener and Grimaldi, 1988a) from the nearctic region and in Tetragonula devicta from Burma (cf Kerr and Maule, 1964; Wille, 1977; Moure and Camargo, 1978). This grouping as proposed by moure (1961), was regarded by Michener as a single genus, Trigona, from which only Oxytrigona and Cephalotrigona were excluded, being considered as specialized genera associated to the clade. He also excluded Dactylurina, which, in spite of presenting this character state and others in common with the Trigona line (eg plumose hairs along the posterior margin of the hind tibia, and an area in the hind basitarsus of $D$ staudingeri, similar to the sericeous area of the Trigona), is considered by Michener (1990), to be closely related to Plebeina, another phyletic line from Africa, based on the male and worker gonostylus form and male gonocoxyte.

Other characters, such as the sericeous area on the base of the inner surface of the hind basitarsus of the worker (a well defined area of dense micropilosity), place the Indo-Malayan groups of Trigona (sensu lato) line, except Lepidotrigona, Homotrigona and Papuatrigona, directly as a sister-group of Tetragonisca and Trigona (s str) from the neotropical region. However, this character can be plesiomorphic for Trigona (s lat). A sericeous area is also present in the fossil $T$ prisca. In addition to this character, Tetragonisca angustula Latreille has a structure interpreted as the 8th metasomal sternum (Camargo, in litt), which also indicates a plesiomorphic condition.

\section{The Plebeia line}

This line is poorly defined and the relations among included taxa are obscure and doubtful. According to Moure (1951), this line includes the groups that have enlarged 
keirotrichia, leaving only a narrow posterior margin, depressed or not. They are as follows: from the neotropical region, Plebeia (s str), Mourella, Friesella, Schwarziana, and the associated genera Melipona, Scaura, Schwarzula, Partamona, Parapartamona and Nogueirapis, and possibly more remotely derived ParatrigonaAparatrigona and NannotrigonaScaptotrigona; from the Ethiopian region, Plebeina, Plebeiella and Meliplebeia, and from Australia and New Guinea, Austroplebeia. Michener (1990) nevertheless, did not consider these African and Australian taxa as sister-groups of the neotropical groups; for the African forms he suggested a relationship with neotropical Trigonisca (s lat) and Hypotrigona from Africa. Michener had good reasons for excluding some African groups from a direct relationship with Plebeia. Loss of the rastellum and presence of a well-developed posterior parapenicillum are clear synapomorphies linking Meliponula, Plebejella, Meliplebeia, Axestotrigona and Apotrigona without corresponding forms in other continents, so that he considered them to belong to a single genus: Meliponula. The inclusion of Hypotrigona-Liotrigona in this clade seems logical, since the modifications in the rastellum (soft hairs) and posterior parapenicillum, are similar to that of Meliponula (sensu Michener). On the other hand, contrary to Michener's interpretations, Plebeina presents a functional and well developed rastellum and an undeveloped parapenicillum, exactly like those of Plebeia (s str). Unless this character (rastellum) arose by reversion or de novo (which is perfectly possible, since it is only a comb of modified setae), such a feature could indicate a relationship between Plebeina and neotropical forms (Michener codified rastellum as weak or absent in Plebeina, Austroplebeia, Dactylurina and Trigonisca s lat, nevertheless, it is present and functional in all of them). Other char- acters linking the African forms (including Dactylurina and Plebeina) with the exception of Hypotrigona, are the gonostyli in workers, enlarged and diverging apically and covered with micropilosity. Michener (1990:88, characters $11,12,13)$ considered the worker gonostyli to be well separated at the base, converging apically and covered with abundant long bristles and with absence of micropilosity, as plesiomorphic states. We are of the opinion that the polarity of the latter character $(0=\mathrm{mi}-$ cropilosity absent; 1 = present), is improbable. If it is considered that reduced sting without biological function is not subjected to selective pressure at least theoretically, it therefore should not acquired new attributes only to suffer reduction or loss of structures (unless it is supposed that reduction of the sting occurred at least twice independently in ancestors of the Meliponinae). In this way, bristles and micropilosity would appear in combination in the ancestor (loss of micropilosity and bristles might occur independently). This combination association to cylindrical and convergent gonostyli, in our view, occurs in Trigonisca, (s lat, cf Michener, 1990; figs 38, 39), from the neotropical region, and indicates an approximation to Plebeina, if it is also considered that both have a well developed and functional rastellum. Although the relationships between the African and neotropical taxa are still unclear, Michener (1990) also recognized a closer relationship between them, rather than with any other taxon from other continents.

Among the neotropical taxa associated with the Plebeia line certain problems also arise. According to the characters considered by Michener (1990), Melipona arises at the base as an isolated branch, a sistergroup of the other Meliponinae. The acute submarginal angle in the forewing constitutes the main synapomorphy that separates Melipona from the Plebeia branch and associated taxa; this, however, is a difficult 
character to codify. An acute angle $\left(=75^{\circ}\right)$ occurs in some species of Paratrigona (another plesiomorphic character in this genus is the presence of the 2 submarginal cells, which are very well delimited in some species; cf Camargo and Moure, 1992), while in Melipona, in some forms of the marginata group, this angle is practically at a right angle $\left(85-90^{\circ}\right)$. Some doubts about the form of the male genital capsule (rectigonal, schizogonal) also remain, eg the schizogonal condition of Melipona also appears, according to Michener (1990) in some other taxa such as Nannotrigona. Reevaluation of these characters could bring Melipona much nearer the Plebeia branch, or even place it as a derivative group of the Plebeia stock. On the other hand, Plebeia (s str), even taking into account some of the characters considered by Michener (1990), seems to be a derivative form. For example, the median apical process of the 6th metasomal sternum of the male (a plesiomorphic state, $c f$ Michener, 1990:88), present in most of the other taxa, including Mourella (considered synonymous with Plebeia s str by Michener, 1990), is absent in Plebeia (s str). Moreover, Mourella exhibits a set of other bionomic characters associated with subterranean nesting habits (simple nest entrance, not delimited by resin or cerumen, gallery between the surface and the nest not lined with cerumen, listed amcing others by Camargo and Wittmann, 1989), considered by us as plesiomorphic states.

For Austroplebeia, the problems are just as numerous. In the cladograms of Michener (1990), it appears related to derivative African forms, mainly because of the way in which the characters were codified, particularly the main synapomorphy, rastellum absent. On the contrary, Austroplebeia has a well developed and functional rastellum, as in neotropical Plebeia (s str). Taking into account male genital characters, with the exception of the absence of spatha, even Michener (1990) recognized an approximation to neotropical forms. Furthermore, other characters such as unmodified pregenital sterna and the 6th metasomal sternum with a median apical process in males, general body form, triangular hind tibia, enlarged keirotrichia, and rastellum present in workers are suggestive of a relationship with the neotropical Plebeia line, primarily Mourella. It is less probable that such a combination of character states, even if they are considered as plesiomorphic states, is present in unrelated taxa (see also Camargo and Wittmann, 1989 ) or arises convergently, as suggested by Michener (1990:104); there is no known determinant factor of convergence for such a set of characters. With reference to the sting structure of Austroplebeia, cylindrical gonostylus, covered with micropilosity and setae (or bristles) are plesiomorphic states and are also present in neotropical forms (Trigonisca). in fact, in our opinion Austroplebeia does not share apomorphies with any other taxa, but exhibits a series of plesiomorphic states, resembling neotropical forms rather than African forms.

Fossils related to Plebeia (s str) have been described from the Oligocene Amber, Chiapas, Mexico (Nogueirapis silacea Wille, 1959) and from the Oligocene Amber of the Dominican Republic (Proplebeia dominicana; cf Michener, 1982).

\section{The Hypotrigona line}

This line includes Hypotrigona (s str) and Liotrigona from Africa, Trigonisca, Leurotrigona, Celetrigona and Dolichotrigona from the neotropical region, and Pariotrigona and Lisotrigona from Indo-Malaya. These are the smallest Meliponinae known (ca $2.0 \mathrm{~mm}$ ) and, according to Moure (1961), most of the characters considered could indicate convergence associated with reduc- 
tion in body size rather than phylogenetic relatonships. In Michener's cladograms they appear as related taxa, with the exception of Liotrigona. According to Michener (1990), the long malar space, nearly right-angled submarginal angle and bristles arranged in successive transversal rows on the inner surface of the hind basitarsus of Pariotrigona suggest some species of the neotropical Trigonisca (s lat). Males of Pariotrigona which might corroborate or refute such a relationship, are not known.

Fossils, possibly related to Hypotrigona (s lat), have been described from the Eocene Baltic Amber (Kelneriapis eocenica; cf Moure and Camargo, 1978; Sakagami, 1978) and from the East African Copal (Hypotrigona gribodoi; cf Wille, 1977). Liotrigona vetula was described by Moure and Camargo (1978) from a Copal piece of unknown age and origin.

An analysis of all taxa, taking into account the biogeographic regions, allows the following relationships to be suggested:

- Between neotropical and African regions there are no defined sister-groups, but indications of possible relationships among Plebeina, Plebeia line and Trigonisca (s lat) and between Hypotrigona and Trigonisca (s lat), as suggested by a still confused combination of plesiomorphies and apomorphies. The conspicuous divergence of the remaining African taxa and the absence of representatives from the TetragoniscaTetragona line (except possibly Dactylurina as a relict form) in Africa indicate, according to Michener (1990:97), that the African fauna must have evolved in substantial isolation from African and Eurasian invasions.

- Between the neotropical and Malayan regions, the relationships are more clearly defined by the presence of sister groups from the Tetragonisca-Tetragona line (Trigona $s$ lat) and also by possible rela- tionships between Trigonisca ( $s$ lat) and $L i$ sotrigona and Pariotrigona.

- Between the neotropical region and Australia and New Guinea, there is no defined sister-group, but indications of a close relationship between the Plebeia line and Austroplebeia exist.

- Between the African and Malayan regions, sister-groups do not occur. There are only indications of a relationship between Hypotrigona and Pariotrigona. In the Malayan region there are no forms related to the Plebeia line. Between Africa and Australia, there is no sister group.

- From the Malayan taxa, 3 genera occur in New Guinea and only 1 in Australia. Austroplebeia only occurs in New Guinea and Australia.

The hypothesis suggested by Michener (1990) of an origin in North America (West Laurasia) seems well sustained in his cladograms (figs $6,7,8$ ) and in the fossil record ( $T$ prisca). He suggested that the present vicariance pattern in the Meliponinae results from a distribution throughout the holarctic region which took place when this area was warmer. He considered the discontinuity between the neotropical and African fauna as indicative that the Meliponinae from North America reached South America after considerable separation between the latter and Africa, and that the African fauna evolved when Africa was substantially isolated from American and Eurasian invasions. On the other hand, the indication of a relationship between Austroplebeia from Australia and the Plebeia line from the neotropical region rather than with African forms, and the absence of forms related to this group in the Indo-Malayan region, are suggestive of a panaustral migration route via Antarctica (Camargo, 1989; Camargo and Wittmann, 1989). This pattern is indicative of the presence of the Meliponinae in Southern South America; at least between the Upper Cretaceous and 
the Early Tertiary. Also, the presence of Plebeia line forms restricted to southern Brazil, especially Mourella, as previously discussed, suggests the origin of this group (Plebeia line) in the southern southAmerican cratons (Camargo, 1989, 1990; Camargo and Wittmann, 1989). This possible antiquity of the Plebeia line (a basic branch in the cladogram of Michener, 1990) in South America, and the indication of a more remote relatonship between the neotropical and African taxa (cf Michener, 1990), as already discussed, are suggestive that a West Gondwanan origin for Meliponinae is also a plausible hypothesis (Camargo, 1989, 1990; Michener, 1979; Roubik, 1989). Thus, the Malayan and Australian taxa would be derived from the neotropical stock, possibly after the split from Africa.

The presence of sister-groups from the Tetragonisca-Tetragona line in Malayan and neotropical regions, and absence of related taxa in Africa suggest an ancient connection track, via the holarctic region, before the separation of West Eurasia and North America, and before the formation of the immense Himalayan mountain range by the collision of India with Asia, a remarkable barrier to recent fauna. The presence of fossils from the Upper Cretaceous in New Jersey, USA ( $T$ prisca, related to Tetragonisca-Tetragona line) and from the Eocene Amber Baltic (Kelneriapis eocenica, related to Hypotrigona line) are possible indications of this migratory route. An ancient communication between South and North America, via the proto-Caribbean arc, in the Early Tertiary (Camargo et al, 1988) or in the Upper Cretaceous, has been proposed for bees and other fauna ( $c f$ Savage, 1983; Rage, 1986; Guyer and Savage, 1987; Roubik, 1990; see also the literature in Savage, 1991). The neotropical Tetragona-Tetragonisca group has its greatest diversity and dispersal center at the Guyana and northern Brazil shields.
India, in isolation for a long period ( $c f$ literature in Patterson and Owen, 1991) possibly did not participate in the dispersal of the Meliponinae, and was invaded later by Malayan Trigona (s lat) (this would explain the presence of only about 5 species on eastern India). The invasion of New Guinea and Australia by Trigona (s lat) taxa of the Malayan region seems to be much more recent.

The hypotheses of Kerr and Maule (1964), who supposed that the Meliponinae originated in South America and migrated to North America during the Eocene, and via the Bering strait to other continents, and that of Wille (1979b, 1983) who suggested an African origin in the Upper Cretaceous-Lower Tertiary, and migration to Europe during the Tertiary, and from there to the other continents, are not supported, in view of recent evidence on the antiquity of this group and relationships among the taxa.

\section{ACKNOWLEDGMENTS}

We thank $R$ Zucchi and $C D$ Michener for suggestions and De Jong for correcting the language and style, anonymous referees for corrections and suggestions. This project received financial support from the FINEP, CNPq and FAPESP; JMFC is a CNPq associate researcher, Ref 300014/84-8/ZO/FV.

\footnotetext{
Résumé - Systématique, phylogenèse et biogéographie des Meliponinae (Hymenoptera, Apidae) : synthèse. Dans cet article de synthèse sont discutées les principales propositions concernant la systématique, la phylogenèse et la biogéographie des Meliponinae, ainsi que la polarité et l'importance de quelques caractères morphologiques. Bien que tout un ensemble de synapomorphies (par ex les corbicules, le rastellum, l'articulation du basitarse postérieur près de l'extrêmité antérieure de
} 
l'apex du tibia) suggèrent que les Meliponinae constituent un groupe cophylétique des Apinae, des Bombinae et des Euglossinae, leurs relations avec ces sousfamilles restent floues. Leur répartition géographique (Meliponinae : zone pantropicale; Bombinae : zone holarctique; Euglossinae : zone strictement néotropicale; Apinae, principalement indo-malaisienne) et les données des fossiles indiquent un âge très ancien pour les Meliponinae (le plus vieux fossile, Trigona prisca, provenant de l'ambre du New Jersey, USA, est daté du Crétacé, soit 96-74.106 ans) et suggèrent une origine indépendante ou une divergence très précoce d'une branche des proto-Apidae. L'interprétation de certains caractères (par ex rastellum, keirotrichia, angle submarginal de l'aile antérieure), présentée dans une analyse cladistique récente (Michener, 1990), est discutée. Une autre polarité pour les caractères de l'aiguillon est suggérée $(0=$ gonostyle avec micropilosité abondante, $1=$ micropilosité absente). L'absence de représentants semblables à Plebeia en IndoMalaisie et des indications selon lesquelles Austroplebeia (d'Australie) est étroitement apparentée à la lignée Plebeia des néotropiques (dont les centres de diversité et de dispersion sont situés dans les boucliers du Brésil méridional) suggèrent l'existence d'une voie de liaison panaustrale et la présence de Meliponinae en Amérique du Sud au moins entre le Crétacé supérieur et le début du Tertiaire. Les relations phylogénétiques probables et la répartition géographique laissent à penser que l'origine gondwanienne occidentale des Meliponinae est une hypothèse plausible. Les relations de groupes sœurs entre les taxons de Malaisie et la lignée TetragonaTetragonisca (dont les centres de dispersion et de diversité se situent dans les boucliers des Guyanes et du Brésil septentrional), telles que les indiquent certaines synapomorphies, et une relation possible entre Trigonisca (s lat) et Lisotrigona et Pariotrigona suggèrent une liaison ancienne, peut-être du Crétacé supérieur, à travers la région holarctique. Les formes fossiles du New Jersey et d'Eurasie (ambre de la Baltique) sont une preuve éventuelle de cette route de migration. L'Inde n'a vraisemblablement pas pris part à la dispersion des Meliponinae et n'a été colonisée que plus tard à partir de la Malaisie. L'absence de représentants de la lignée Tetragona-Tetragonisca en Afrique et la grande divergence des taxons présents sur ce continent indiquent une longue période d'isolement. Néanmoins des relations plus étroites avec les taxons néotropicaux (lignée Plebeina-Plebeia et Trigonisca $s$ lat, Hypotrigona et Trigonisca) qu'avec tout autre taxon des autres continents sont suggérées par une combinaison confuse de plésiomorphies et d'apomorphies.

\section{systématique / biogéographie / phyloge- nèse / Meliponinae / Apidae}

Zusammenfassung - Systematik, Phy-
logenie und Biogeographie der Melipo-
ninen (Hymenoptera, Apidae): Eine Mini-Review. In dieser Ubersicht werden die wichtigsten überlegungen zur Systematik, Phylogenie und Biogeographie der Stachellosen Bienen, sowie die Polarität und Bedeutung einiger morphologischer Merkmale diskutiert. Obwohl eine ganze Reihe von Synapomorphien (zB Corbicula, Rastellum, Artikulation des hinteren Basitarsus nahe dem vorderen Ende der Tibiaspitze) die Einordnung der Meliponen als co-phyletische Gruppe mit den Apinen, Bombinen und Euglossinen nahelegt, bleiben doch die Beziehungen zu diesen Unterfamilien unklar. Geographische Verteilung (Meliponinen - pantropisch, Bombinen - holarktisch, Euglossinen - streng neotropisch, Apinen - vorwiegend indomalayisch) und fossile Funde deuten auf 
ein größeres Alter der Meliponinen hin (das älteste Fossil, Trigona prisca, aus einem Bernstein aus New Jersey, USA, 96-75 $10^{6}$ Jahre) und lassen einen unabhängigen Ursprung oder eine frühe Abzweigung von einem Ur-Apidenzweig vermuten. Die Interpretation einiger Merkmale in einer kürzlich publizierten kladistischen Analyse der Meliponinen (Rastellum, Keirotrichia, submarginaler Winkel des Vorderflügels) wird diskutiert. Außerdem wird eine andere Polarität von Stachelmerkmalen vorgeschlagen $(0=$ Gonostylus mit reichlicher Mikropilosität, 1 $=$ Mikropilosität fehlend).

Die Abwesenheit von Plebeia-ähnlichen Vertretern in Indo-Malaya und die Verwandtschaft als Schwestergruppen von malayischen und neotropischen Meliponinen (die Linie Tetragona-Tetragonisca und möglicherweise TrigoniscaPariotrigona, Lisotrigona) so wie die mögliche Verwandtschaft zwischen Austroplebeia und der neotropischen Plebeia-Linie legen einen panaustralischen Verbindungsweg und einen weiteren über die holarktische Region (möglicherweise in der oberen Kreide) nahe. Die Anwesenheit von meliponinen im südlichen Südamerika (mindestens zwischen der oberen Kreide und dem frühen Tertiär) ist wahrscheinlich. Diese phylogenetischen Beziehungen und Ausbreitungsmuster machen die Hypothese eines Ursprungs der Meliponen aus West-Gondwana plausibel. Fossile Funde in New Jersey, USA, und Eurasien (Baltischer Bernstein) sind mögliche Beweise für diese Wanderungsrouten. Indien war wahrscheinlich an diesen Ausbreitungswegen nicht beteiligt, sondern wurde erst später von Malaya aus besiedelt. Das Fehlen der Tetragona-TetragoniscaGruppe in Afrika und die große Divergenz der auf diesem Kontinent vorhandenen Taxa weisen auf eine lange Isolationsperiode hin. Es bestehen jedoch Hinweise einer näheren Verwandtschaft zu den neotropischen Taxa (Plebeina-Plebeia-Gruppe und Trigonisca, sensu lato: Hypotrigona und Trigonisca), nahegelegt durch eine verwirrende Kombination von Plesiomorphien und Apomorphien, als zu Gruppen von anderen Kontinenten.

\section{Systematik / Biogeographie / Apidae / Meliponinae / Phylogenie}

\section{REFERENCES}

Alexander BA (1991) Phylogenetic analysis of the genus Apis (Hymenoptera: Apidae). Ann Entomol Soc Am 84(2), 137-149

Camargo JMF (1972) Notas prévias sobre o trato genital de rainhas de Apis dorsata e Apis florea (Hymenoptera, Apidae). In: Homenagem à WE Kerr. Rio Claro, 47-56

Camargo JMF (1989) Comentários sobre a sistemática de Meliponinae (Hymenoptera, Apidae). In: An XIV Simp Anual da ACIESP. 68 (suppl), 41-61

Camargo JMF (1990) Stingless bees of the Amazon. In: Proc 11th IUSSI Int Congr: Social Insects and the Environment (Veeresh GK, Mallik B, Viraktamath CA, eds) Bangalore, India, 736-738

Camargo JMF, Moure JS (1983) Trichotrigona, um novo genero de Meliponinae (Hymenoptera, Apidae) do rio Negro, Amazonas, Brasil. Acta Amazonica 13 (2), 421-429

Camargo JMF, Moure JS (1988) Notas sobre os Meliponinae (Hymenoptera, Apidae) colecionados por Felippo Silvestri na Bacia do rio Prata. Rev Bras Entomol 32 (2), 293-314

Camargo JMF, Wittmann D (1989) Nest architecture and distribution of the primitive stingless bee, Mourella caerulea (Hymenoptera, Apidae, Meliponinae): evidence for the origin of Plebeia (sensu lato) on the Gondwana continent. Stud Neotrop Fauna Environ 24 (4), 213-229

Camargo JMF, Moure JS (1992) Os generos Paratrigona Schwarz, 1938 e Paratrigona Moure, 1951 (Hymenoptera, Apidae, Meliponinae). Arq Zool (São Paulo) (in press)

Camargo JMF, Moure JS, Roubik DW (1988) Melipona yucatanica new species (Hymenoptera: Apidae: Meliponinae); stingless bee dis- 
persal across the Caribbean Arc and postEocene vicariance. Pan-Pac Entomol 64 (2), 147-157

Cameron SA (1991) A new tribal phylogeny of the Apidae interred from mitochondrial DNA sequences. In: Diversity in the Genus Apis (Smith DR, ed) Westview Press / Oxford and IBH Publishing Co Pvt Ltd Boulder, CO, 71 87

Cruz-Landin C (1967) Estudo comparativo de algumas glandulas das abelhas (Hymenoptera, Apoidea) e respectivas implicações evolutivas. Arq Zool S Paulo 15, 177-290

Friese $H(1920)$ Canephorula apiformis Friese (Hymenoptera), eine Bienen-Art mit dem Beginne der Koerbchenbildung aus Argentinien. Zool Jahrb Abt Syst Oekol Geogr Tiere 43, 461-470

Grimaldi D, Beck CW, Boon JJ (1989) Occurrence, chemical characteristics, and paleontology of the fossil resins from New Jersey. Am Mus Novit 2948, 1-27

Guyer C, Savage JM (1987) A cladistic classification of anoles (Scauria: Iguanidae). Syst Zool 35, 509-531

Kerr WE, Maule V (1964) Geographic distribution of stingless bees and its implications (Hymenoptera: Apidae). J NY Entomol Soc 72, 2-17

Kimsey LS (1984) A re-evaluation of the phylogenetic relationships in the Apidae (Hymenoptera). Syst Entomo/ 9, 435-441

Michener CD (1944) Comparative external morphology, phylogeny and a classification of the bees (Hymenoptera). Bull Am Mus Nat Hist 82, 151-326

Michener CD (1979) Biogeography of the bees. Ann Missouri Bot Gard 66, 277-347

Michener CD (1982) A new interpretation of fossil social bees from the Dominican Republic. Sociobiology 7, 37-45

Michener CD (1990) Classification of the Apidae (Hymenoptera). Univ Kansas Sci Bull 54 (4), 75-164

Michener CD, Grimaldi DA (1988a) A Trigona from late Cretaceous Amber of New Jersey (Hymenoptera: Apidae: Meliponinae). Am Mus Novit 2917, 1-10

Michener CD, Grimaldi DA (1988b) The oldest fossil bee: apoid history, evolutionary stasis, and antiquity of social behavior. Proc Natl Acad Sci USA 85, 6424-6426
Michener CD, Laberge W, Moure JS (1955) Canephorulini, a tribe of South American bees (Hymenoptera-Apoidea). Dusenia 6 (5), 207-212

Michener CD, Winston ML, Jander R (1978) Pollen manipulation and related activities and structures in bees of the family Apidae. Univ Kansas Sci Bull 51 (19), 575-601

Moure JS (1946) Meliponas do Brasil. Chácaras Quintaes, SP, 74, 609-612

Moure JS (1951) Notas sobre Meliponinae (Hymenoptera-Apoidea). Dusenia 2 (1), 25-70

Moure JS (1961) A preliminary supra-specific classification of the Old World Meliponine bees (Hymenoptera, Apoidea). Stud Entomol 4 (1-4), 181-242

Moure JS (1971) Descrição de uma nova espécie de Tetragona do Brasil Central (Hymenoptera, Apidae). Bol Univ Paraná Zool 4 (10), 47-50

Moure JS (1989a) Camargoia, um novo genero Neotropical de Meliponinae (Hymenoptera, Apidae). Bol Mus Paraense Emilio Goeldi Ser Zool 5 (1), 71-78

Moure JS (1989b) Sakagamilla affabra, gen n e sp $\mathbf{n}$ de Meliponinae (Hymenoptera, Apidae) de Rondonia. Rev Bras Zool 6 (4), 681-684

Moure JS, Camargo JMF (1978) A fossil stingless bee from Copal. J Kans Entomol Soc 51 , 560-566

Moure JS, Nogueira-Neto P, Kerr WE (1958) Evolutionary problems among Meliponinae (Hymenoptera, Apidae). Proc Int Congr Entomol $2,481-493$

Patterson C, Owen HG (1991) Indian isolation or contact? A response to Briggs. Syst Zool 40, 96-100

Plant JD, Paulus HF (1987) Comparative morphology of the postmentum of bees (Hymenoptera: Apoidea) with special remarks on the evolution of the lorum. $Z$ Zool Syst Evol Forsch 25, 81-103

Prentice M (1991) Morphological analysis of the tribes of Apidae. In: Diversity in the genus Apis (Smith DR, ed) Westview Press Oxford and IBH Publ Co Pvt Ltd, Boulder, CO, 51-69

Rage JC (1986) South American/North American terrestrial interchanges in the latest Cretaceous: short comments on Brett-Surman and Paul (1985), with additional data. J Vertebr Paleontol 6, 382-383 
Roubik DW (1989) Ecology and Natural History of Tropical Bees. Cambridge Univ Press, Cambridge, UK, $514 \mathrm{pp}$

Roubik DW (1990) Biogeographical ecology of Melipona (Apidae: Meliponinae). In: Proc 11th Int Congr IUSSI: Social Insects and the Environment (Veeresh GK, Mallik B, Viraktamath CA, eds) Bangalore, India, 579-580

Ruttner F (1988) Biogeography and Taxonomy of Honeybees. Springer-Verlag, Berlin, 284 $\mathrm{pp}$

Sakagami SF (1975) Stingless bees (excl Tetragonula) from the Continental Southeast Asia in the collection of Bernice P Bishop Museum, Honolulu (Hymenoptera, Apidae). J Fac Sci Hokkaido Univ, Ser VI Zool 20 (1), 49-76

Sakagami SF (1978) Tetragonula stingless bees of the continental Asia and Sri Lanka. $J$ Fac Sci Hokkaido Univ Ser VI Zool 21, 165247

Sakagami SF, Michener CD (1987) Tribes of Xylocopinae and origin of the Apidae (Hymenoptera: Apoidea). Ann Entomol Soc Am 80 (3), 439-450

Sakagami SF, Inoue T, Salmah S (1990) Stingless bees of Central Sumatra. In: Natural History of Social Wasps and Bees in Equatorial Sumatra (Sakagami SF, Ohgushi R, Roubik DW, eds) Hokkaido Univ Press, Sapporo, 125-137

Savage JM (1983) The enigma of the Central American herpetofauna: dispersals or vicariance? Ann MO Bot gard 69, 464-547

Savage JM (1991) Reviews: biogeography of the West Indies. Past, present and future (Woods CA, ed) Syst Zool 40 (1), 110-111

Schwarz HF (1932) The genus Melipona: the type genus of the Meliponidae or stingless bees. Bull Am Mus Nat Hist 63, 231-460
Schwarz HF (1948) The stingless bees (Meliponinae) of the western hemisphere. Bull Am Mus Nat Hist 90, 1-546

Sheppard WS, McPheron BA (1991) Ribosomal DNA diversity in Apidae. In: Diversity in the Genus Apis (Smith DR, ed) Westview Press of Oxford, IBH Publ Co Put Ltd, Boulder, CO, 89-102

Simpson BB, Neff JL (1985) Plants, their pollinating bees, and the great American interchange. In: The Great American Biotic Interchange (Stehli FG, Webb SD, eds) Plenum, New York, 427-452

Tosi A (1896) Di nuovo genere di Apiaria fossile nell'ambra di Sicilia (Meliponorytes succini, $M$ sicula). Rev Ital Paleontol 2, 352-356

Wille A (1959) A new fossil stingless bee (Meliponini) from the amber of Chiapas, Mexico. $J$ Paleontol 33, 849-852, pl 119

Wille A (1977) A general review of the fossil stingless bees. Rev Biol Trop 25, 43-46

Wille A (1979a) A comparative study of the pollen press and nearby structures in the bees of the family Apidae. Rev Biol Trop 27, 217-221

Wille A (1979b) Phylogeny and relationship among the genera and subgenera of the stingless bees (Meliponinae) of the world. Rev Biol Trop 27 (2), 241-277

Wille A (1983) Biology of the stingless bees. Ann Rev Entomol 28, 41-64

Winston ML (1979) The proboscis of the longtongued bees: A comparative study. Univ Kansas Sci Bull 51 (22), 631-667

Winston ML, Michener Cd (1977) Dual origin of highly social behavior among bees. Proc Natl Acad Sci USA 74 (3), 1135-1137

Zeuner FE, Manning FJ (1976) A monograph on fossil bees. Bull Br Mus Nat Hist (Geol) 27, $149-268,4 \mathrm{pl}$ 